\title{
STATE OF KOSOVO AND ITS RELATIONS WITH INTERNATIONAL COMMUNITY
}

\author{
Halim Bajraktari \\ Prof. ass. dr. Dean- Law Faculty \\ University "Ukshin Hoti" of Prizren, \\ Emurllah Spahiu
}

MSc. Cultural heritage and Tourism management

Sihana Duraku

MSc. Cultural heritage and Tourism management

\begin{abstract}
:
No organization represents community of states more than the United Nations (UN). The UN provides balance, neutrality, security and stability for the international community. States invest more legitimacy in that than any other organization and through its universal membership, it serves as a road and guide to international norms.

In other hand the United Nations doesn't have the competence to recognize states, but states recognize states. If you're not a UN member, it doesn't mean that you're not a state. The four criteria for being a state are determination of a territory, the populations, the government and ability to reach agreement with others.

In this contest Republic of Kosovo is facing difficulties in joining United Nation, and his specialized agencies, also facing the difficulties, to join international organizations as a way to secure recognition and complete statehood in international arena. Showing the will and the determination to respect international obligation regulated by each specialized agency and organization, the process of application in UNESCO is the case which shows how the states are devided in international arena, and one of the major failure of Kosovo foreign policy and diplomacy after rejection of Kosovo bid to join UNESCO in 2015.
\end{abstract}

The application process and steps followed by Kosovo institutions, decisions and recommendation of the UNESCO executive board, discussed on the General Conference, part of the general conference discussion related to the Kosovo application and voting process on the General Conference distribution of votes from the states who voted in favor, against, abstention and absence during General Conference and rejection of Kosovo bid. And the conclusions while what are the benefits on joining the UNESCO and the consequences for Kosovo in the rejection of bid to obtain a seat at the organization UNESCO, what are the next steps and the 
chances of Kosovo Institution and recommendations for future, and selection of approaches on the second bid to join UNESCO in the near future.

Key word: International community, UN special agencies, UNESCO, statehood, Executive Board, General Conference, admision, Republic of Kosovo, rejection.

\section{STATE OF KOSOVO AND ITS RELATIONS WITH INTERNATIONAL COMMUNITY}

\section{Problem anaysys and research goal}

International recognition of the states is initially one of the main challenges of the new states and this is crucial for a country in order to find the easier to way to join the United Nations (UN), specialized agencies, institutions and other intergovernmental organizations, political, economic, cultural, sports, scientific, etc. Another challenge for the new states is to create an influential position and place on the global scene, but it is also determined by military, economic, political power on the regional context of the geo-strategic position in which it is located, as well as state orientations and anions / positioning from the major military and economic powers of the world who are the global factor in regulating the system and global rules.

As for the Republic of Kosovo, after the declaration of independence on 17 February 2018 ${ }^{1}$, its commitments as a state remain the pro-Western orientation, trying to take an integrative step with the countries of the region in the Euro-Atlantic integration processes, being beside the states which have helped them in the process of liberation, state-building and integration into international organizations and agencies. Therefore, one of the priorities of the government is to overcome the challenges and find the shortest path to Kosovo's membership in the UN.

To join international agencies and organizations, whose goal is ranked among the top priorities of Kosovo's foreign policy, priorities promoted and affirmed by key government officials, including the President, Prime Minister, Minister of Foreign Affairs, Ministries and lobbying organization around the world, among them the most influential ones in the United States and Great Britain.

This comes as a natural result of the ongoing integration and globalization processes in which Kosovo wants to integrate quickly and it is thought that membership processes in international organizations will be concluded much faster than what is actually happening in recent years due to developments in the world, but also the extreme polarization of society and the internal battles for power by the numerous political parties in Kosovo, which create additional obstacles to achieving these goals.

\footnotetext{
${ }^{1}$ Declaration of Independence https://www.assembly-kosova.org/common/docs/Dek_Pav_e.pdf (consulted on date; 02.11.2018)
} 
Since its declaration of independence in 2008, Kosovo is a member of 64 international and regional organizations ${ }^{2}$. In addition, Kosovo is a member of two United Nations Specialized Agencies (IMF and World Bank) and a member of two organizations closely linked to the Council of Europe, the Venice Commission and the European Bank for Reconstruction and Development. To date, Kosovo has adhered to several Multilateral Conventions, namely the Apostle Convention, Hague Convention (through which it became a member of the Permanent Court of Arbitration) and the International Customs Organization ${ }^{3}$. But the priority of Kosovo's diplomacy over the last few years remains a change in approach and that from bilateral integration to multilateral integration has been crowned with important achievements in recent years, so for MFA and Kosovo institutions, multilateral integration has become the main success of Kosovo diplomacy in the international arena ${ }^{4}$.

No organization represents community of states more than the United Nations (UN). The UN provides balance, neutrality, security and stability for the international community. States invest more legitimacy in that than any other organization and through its universal membership, it serves as a road and guide to international norms.

In other hand the United Nations doesn't have the competence to recognize states, but states recognize states. If you're not a UN member, it doesn't mean that you're not a state. The four criteria for being a state are determination of a territory, the populations, the government and ability to reach agreement with others. (Alesdeir Bell 2016), taking in to the consideration those explanation, criteria for mutual recognitions of states lays on individual states to decide whether will recognize and enter in to bilateral agreement or not, it's a sovereign choice of the state itself.

\section{CHALLENGES OF KOSOVA TOWARDS MEMBERSHIP IN INTERNATIONAL ORGANIZATIONS}

If an organization can be considered as a place of meeting and recognition for a state and society, then that place is the United Nations (UN). The United Nations is the ultimate address of the conclusion of the international subjectivity of Kosovo, so acceptance in this organization would legitimize Kosovo as a full-fledged state in the international arena alongside peoples and large and small states of the world .

By joining the United Nations, and its specialized agencies, Kosovo would immediately establish bilateral and multilateral relations with countries that are reluctant to recognize independence and enter into mutual relations with the state of Kosovo 5 .

\footnotetext{
${ }^{2}$ Pristina Institute for Political Studies Report, pg. 5-7 Kosovo's_Multilateral_Integration_-_June 2018.pdf

${ }^{3}$ Ratification of Apostle convention https://www.kuvendikosoves.org/common/docs/ligjet/05-L093\%20sh.pdf(consulted on date; 22.10.2018)

${ }^{4}$ Kosovo Foreign policy Priorities http://www.mfa-ks.net/politika/481/prioritetet-e-reja-t-politiks-s-jashtme-tkosovs/481 (consulted on date; 24.10.2018)

${ }_{5}^{5}$ Unatid Nations and new world order https://www.britannica.com/topic/diplomacy\#ref233755(consulted on date; 26.10.2018)
} 
Upon accession to the UN automatically states are admitted to specialized UN organizations and agencies, with this move Kosovo would receive international obligations and at the same time would benefit from access to funds from specialized agencies, where for the moment besides the World Bank and the International Monetary Fund ${ }^{6}$, Kosovo has no direct access to other agencies.

The fact is that the vast majority of Kosovo's recognitions are made thanks to the work and insistence of states sponsors of Kosovo's independence and those who support this statehood since the beginning of the status process. If you can see the map of the world with the states that have recognized Kosovo, it is clear that the word is for countries with great influence on Western powers such as the United States of America, Great Britain, France, Germany and Turkey. Recognitions have been missing from countries where Russia and Spain have an impact. Russia to the countries of the former Soviet Union and to some Islamic countries, which have antiWestern stance, while Spain in some countries in North Africa and Latin America.

Oposing of recognision of independence of Kosovo by the $5 \mathrm{EU}$ member states has made life difficult for Kosovo and has made it difficult for the EU to realize the enlargement policy in the Balkan region. Dissatisfaction has also made it difficult for Serbia to face the new reality that Kosovo is a state. This was privately said by some Serbian politicians who, before declaring independence, had warned that if there are countries that will not recognize Kosovo, then Serbia can not do it.

At this point we are still today, ten years after the declaration of Independence. While, over time, Serbia is being encouraged, hoping that one day the international circumstances will change and may turn the situation to Kosovo in its favor.

In any situation, the Republic of Kosovo must prove that it is capable and willing to accept international obligations and to appear as a serious partner in the relations with the international community.

By fulfilling international obligations unilaterally, such as the implementation of international conventions and the change of state laws by harmonizing and advancing to the highest standards, by advancing institutional mechanisms for the preservation and protection of cultural and natural heritage, which emerge as commitments for self-respect and implementation of international obligations, Kosovo gives the message that it is a state devoted to respecting international obligations and norms.

Kosovo is a new reality in the Balkans and Europe, as aid to the youngest state has not lacked political, economic and social support through various projects and programs by agencies and organizations that come from friendly and spousorizing states of independence. By orienting Kosovar society towards functional democracy. The socio-economic situation, the negative news about riots, youth migration, unstable political situations, organized crime, corruption, negative reports are negative messages for the state of Kosovo in the eyes of the world, the challenges that need to be overcome if Kosovo wants to provide a meritorious place in clubs and organizations of progressive nations.

\footnotetext{
${ }^{6}$ Integrating Kosovo into the United Nations System GLPS-Policy-Report-INtegrating-Kosovo-into-the-UNSystem.pdf (consulted on date; 01.11.2018).
} 


\section{RULES AND PROCEDURES OF MEMBERSHIP IN UNESCO}

One of the major failures on the foreighn affairs and Kosovo diplomatic effort, after the declaration of Kosovo's independence was the non-acceptance of Kosovo to joint UNESCO in 2015, Kosovo failed to become a member for only three votes. The whole process that Kosovo follows for joining the UNESCO as a non UN member state, which issue raises many questions, turning to UNESCO's admission regulations, which the right to enter the organisation is regulated by the UNESCO constitution ${ }^{7}$.

UNESCO is created with the mission of reaching peace and cooperation among peoples through culture, science and education. The UNESCO founding idea stems from the approach by which politics and economics are not enough to achieve reconciliation between people and nations in the world. Today, UNESCO counts 195 member states and 11 associate members ${ }^{8}$, this number clearly exceeds the number of UN member states as the founding organization, this number is a proof that joining an international organization helps new states to avoid bilateral recognition by states individually but with membership in UN special agencies this is easies way to confirm international subjectivity of new state. The most typical example when an entity without a recognized international subjectivity has managed to join a multilateral organization is the acceptance of the Palestinian Authority in UNESCO on 23 November, $2011^{9}$.

Membership of states in UNESCO is regulated with the Constitution and the Rules of Procedure of the General Conference. According to Article II, paragraph 1 of the UNESCO Constitution, Membership of the United Nations Organization shall carry with it the right to membership of the United Nations Educational, Scientific and Cultural Organization. However, Article II also foresees a procedure for non-member countries of the UN: paragraph 2 of Article II provides that, "Subject to the conditions of the Agreement between this Organization and the United Nations Organization, approved pursuant to Article $X$ of this Constitution ${ }^{10}$, states not members of the United Nations Organization may be admitted to membership of the Organization, upon recommendation of the Executive Board, by a two thirds majority vote of the members of the General Conference." 11 The Rules of Procedure of the General Conference also define the procedure for the admission of new members to the Organization. Rule 85 of Chapter XV Voting requires a two-thirds qualified majority of Members present and voting for the admission of new Member States which are not Members of the United Nations, on the recommendation of

\footnotetext{
${ }^{7}$ UNESCO constitution http://portal.unesco.org/en/ev.php URL ID=15244\&URL DO=DO TOPIC\&URL SECTION=201.html (consulted on date: 15.09.2018)

${ }^{8}$ UNESCO member state https://en.unesco.org/countries/member-states (consulted on date 16.09.2018)

${ }^{9}$ UN news 31 October 2011 Palestinian admission in UNESCO https://news.un.org/en/story/2011/10/393562unesco-votes-admit-palestine-full-member (consulted on 17.10.2018)

${ }^{10}$ Article $X$ of the constitution http://portal.unesco.org/en/ev.phpURL_ID=15244\&URL_DO=DO_TOPIC\&URL_SECTION=201.html (consulted on 20.09.2018)

${ }^{11}$ The Rules of Procedure of the General Conference can be accessed at UNESCO basic documents: http://unesdoc.unesco.org/images/0021/002161/216192e.pdf （consulted on 21.09.2018)
} 
the Executive Board Rule 99, paragraph 1 provides that, "Any state not a Member of the United Nations which desires to become a Member of UNESCO shall submit an application to the General Secretariat. This application shall be accompanied by a statement that the particular state is willing to abide by the Constitution, to accept the obligations contained therein and to contribute to the expenses of the Organization ${ }^{12}$," 4 while Rule 100 provides that, "Applications by states not Members of the United Nations for membership of UNESCO shall, upon recommendation of the Executive Board, be dealt with by the General Conference in accordance with the provisions of Article II, paragraph 2, of the Constitution.

The Rules of Procedure of the General Conference describe the procedure to be followed by the states for membership in UNESCO, in the case of Kosovo all this rules and procedures are followed. Under these rules, any non-member United Nations which wishes to become a UNESCO member must submit an application to the Director-General, in this case Kosovo's request has been addressed to the Executive Board's Director on 4 August 2015 by the side of the Ministry of Foreign Affairs at that time by the Deputy Prime Minister and Minister of Foreign Affairs, which is part of the session document no. $197 \mathrm{EX} / 43^{13}$, explaining how Kosovo has expressed readiness to join UNESCO's organization.

This document clarifies that this request / article is included in the Executive Board's Agenda in its 197 Session at the request of Albania and co-sponsored by Austria, Bahrain, Belize, Burkina Faso, Chad, Costa Rica, Ivory Coast, Denmark, Dominican Republic, Guinea, Haiti, Honduras, Ireland, Jordan, Kuwait, Latvia, Lesotho, Luxembourg, Netherlands, Oman, Panama, Papua New Guinea, Qatar, Elbasan, Gambia, Saudi Arabia, Senegal, Slovenia, Somalia , South Sudan, Sweden, Togo, Turkey, United Arab Emirates, United Kingdom and Northern Ireland, United Republic of Tanzania, United States of America and Vanuatu ${ }^{14}$.

Explanatory Note by: Executive Board 197 session of UNESCO, adressed to the General assembly date 22 Sepetember 2018

1. By letter dated 4 August 2015 addressed to the Director General, His Excellency Hashim Thaçi, First Deputy Prime Minister and Minister of Foreign Affairs of the Republic of Kosovo, applied on behalf of his Government for the admission of the Republic of Kosovo to the United Nations Educational, Scientific and Cultural Organization ${ }^{15}$

2. In accordance with Rule 98 of the Rules of Procedure of the General Conference, this application is accompanied by a statement that the Republic of Kosovo is willing to abide by

\footnotetext{
${ }^{12}$ Quest for Statehood: Kosovo's Plea to Join International Organizations PHD Ermira Mehmeti (consulted on date (consulted on 23.09.2018)

${ }^{13} 43$ Board decision pg.71 (197 EX/43) http://unesdoc.unesco.org/images/0023/002351/235180e.pdf (consulted on date 19.09.2018)

${ }^{13}$ Request of Albania and Co sponsors pg. 1 http://unesdoc.unesco.org/images/0023/002346/234649e.pdf (consulted on date; 22.10.2018)

${ }^{14}$ Application on behalf of ministry of Foreign affairs, pg3

http://unesdoc.unesco.org/images/0023/002346/234649e.pdf (consulted on date; 30.09.2018)
} 
the Constitution, to accept the obligations contained therein and to contribute to the expenses of the Organization.

3. Under the terms of Article II, paragraph 2 of the Constitution of UNESCO, "States not members of the United Nations may be admitted to membership of the Organization, upon recommendation of the Executive Board, by a two third majority vote of the General Conference". As the Republic of Kosovo is not a member of the United Nations, it is the responsibility of the Executive Board to make a recommendation to the General Conference concerning the application for membership.

4. The United Nations Interim Administration Mission in Kosovo (UNMIK) has already confirmed in its letter dated 26 August 2015 that the issue of Kosovo's membership to UNESCO is solely for UNESCO and it s organs to determine

\section{PROPOSED DECISION}

5. The Executive Board,

- $\quad$ Consideringthe request of the Republic of Kosovo for admission to UNESCO submitted on 4 August 2015.

- $\quad$ Having notedthat the Republic of Kosovo accepts UNESCO's Constitution and is ready to fulfill the obligations arising from its admission and to contribute towards the expenses of the Organization.

- $\quad$ Considering Article II, paragraph 2, of the Constitution of UNESCO, which stipulates that . States not members of the United Nations Organization may be admitted to membership of the Organization, upon recommendation of the Executive Board, by a two thirds majority vote of the General Conference".

- $\quad$ Recommends that the General Conference admit the Republic of Kosovo as a member of UNESCO.

The Executive Board adopted this decision following a roll call vote: 27 votes in favour, 14 votes against and 14 abstentions: ${ }^{16}$

AgENDa OF THE 38Th SESSiOn OF THE GENERAL CONFERENCE

Discussion Point 8.3 - The request of the Republic of Kosovo for membership in UNESCO, by a decision of the Board 197 EX / 43 recommends that the Republic of Kosovo be accepted as a member of UNESCO. The decision on this request must be voted on by the General Conference, the subject proposed by Albania. 197 EX / Dec.43, 197 EX / Dec.22 (I), 38 C / 60

The session of the General Conference on 9 November 2015, at the beginning of the General Conference meeting, Serbia, as expected, has requested postponement of the vote on Kosovo's

${ }^{16}$ Voting process in Executive board for decision pg. 71 https://unesdoc.unesco.org/ark:/48223/pf0000235180 
membership in UNESCO. Representatives of the Serbian state have asked for the discussion on Kosovo to be postponed for the next session, with the reason, as they stressed, to give space to the Kosovo-Serbia dialogue on normalization of relations, a dialogue launched in $2013^{17}$.

Immediate replication and response of the UK representative in UNESCO, who stressed that Kosovo's membership in UNESCO and the dialogue between Kosovo and Serbia in Brussels are two separate issues, pointing out that it has never happened that the General Conference refuses a decision of the Executive Board and if this happens it will be a precedent for the future function of organization. This request was also opposed by the German and Austrian ambassadors at UNESCO. The Serbian proposal was put in the vote, and the result was that 89 states have rejected Serbia's request to postpone the vote for reviewing Kosovo's membership in this organization. Meanwhile, Serbia's proposal has supported 59 votes, 22 states have abstained, of the 170 eligible country voters.

Immediately from after the voting process, requested by Serbia, continued the General Assembly meeting, reviewing this item on the agenda and the voting process for Kosovo's accession to this $\operatorname{organization}^{18}$.

\section{VOTING RESULTS IN GENERAL ASSEMBLY RELATED TO THE KOSOSVO BID TO JOIN UNESCO}

Kosovo was not admitted to UNESCO, 142 member's states voted, of which 92 member states voted in "favor" of Kosovo, while 50 member states voted 'against' and opposed their vote for Kosovo's accession to this organization. A total of 29 states abstained, among them states that have recognized Kosovo's independence, while representatives of 15 states were not involved in the voting process and were out of the hall of the General Conference meeting and the voting process.

To win UNESCO membership, Kosovo needed a two-thirds majority. Of the 142 countries that voted, 92 backed the motion, 50 voted against and 29 abstained, meaning the bid fell short by three votes.

\section{IMPORTANCE OF MEMBERSHIP OF THE REPUBLIC OF KOSOVO IN UNESCO}

The failure of Kosovo to join UNESCO is among the strongest setbacks to Kosovo's statehood on international area and its integration. This was one of the biggest diplomatic failures of Kosovo state, since the declaration of independence and as such should serve as a moment of

\footnotetext{
${ }^{17}$ Request of Serbia for postponement of vote, Archive Lajmet pub. 09.11.2015 http://www.arkivalajmeve.com/Deshton-kerkesa-e-Serbise-per-shtyrjen-e-votimit-per-UNESCO.1047881846/ ${ }^{18}$ YOU TUBE Live stream General assembly discussion e 38session of UNESCO https://youtu.be/LQNz4RFdaOM (consulted on date; 30.10.2018)
} 
reflection on important political and institutional point of view including changes. Kosovo and Serbia are in negotiating process since 2012, ${ }^{19}$ and the effects of the negotiations has very significant progress, even after six years of negotiations, while Serbia is using the alibi of negotiation to stop the progress of Kosovo in his path to join international organization and community. Serbia and its allies consider the frozen conflict with Kosovo is an advantage and expect a more favorable moment, even more using favors in the integration processes of Serbia in relation to the European Union.

Kosovo is the only country in the Balkans and in the world that has harmonized and fulfilled the entire legal framework for achieving international standards and obligations on cultural heritage, and protection and conservation of this heritage without being a member of UNESCO. The Kosovo legal framework for the protection of cultural heritage is generally in line with relevant international human rights standards. However, some responsible institutions, such as Kosovo Council for Cultural Heritage and the inter-ministerial working group for communication and implementation have largely remained ineffective.

UNESCO assists member states in developing a system of education, science, culture and quality and inclusive information through building their capacity to design and implement policies in member countries of this organization. Kosovo's membership in the United Nations Educational, Scientific and Cultural Organization of UNESCO will crown its efforts to comply with all international norms, standards and laws in multidimensional field-activity which is included in $\mathrm{UNESCO}^{20}$.

Creating an environment for the development of effective public policies, strictly monitored by commonly accepted rules KOSOVO - UNESCO, is not only a matter of political will but also an issue of institutional legitimacy. UNESCO membership would also have an impact on the strengthening of Kosovo's state subjectivity, entering into bilateral and multilateral relations, but also opening up new opportunities for membership in other UN agencies and ultimately shortening the path to membership of the United Nations. UNESCO will help Kosovo and its people address social and ethical challenges, promote and promote cultural diversity and intercultural dialogue. In practice, the areas covered by this organization in science, culture and education (UNESCO covers over 70 different programs) ${ }^{21}$ in which Kosovo could participate in the first year after membership, where human capacities with great intellectual baggage would be needed.

In the field of cultural heritage, Kosovo would apply for placing under the global protection of all categories of heritage such as: archaeological heritage (sites / reserves), architectural heritage objects, movable heritage, intangible heritage, cultural landscapes and natural heritage. UNESCO's action focuses on the main areas of education where 19 education programs are active $^{22}$, where funds will be allocated to increase the quality of education and school infrastructure at all levels of education and studies. Direct Education Assistance and UNESCO is the issue of reforming, standardizing and exchanging educational programs globally.

\footnotetext{
${ }^{19}$ EU facilitation process Kosovo and Serbia https://eeas.europa.eu/headquarters/headquarters-homepage/14670/eufacilitated-belgrade-pristina-dialogue-implementation-of-the-telecommunications-agreement_en (consulted on date; 14.11.2018)

${ }^{20}$ UNESCO worldwide prorammes www.internationals-buero.de (consulted on date; 11.11.2018)

${ }^{21}$ Educational frame work action $2030 \mathrm{https}$ ://en.unesco.org/themes/education (consulted on date; 28.11.2018)

${ }^{22}$ Educational programs https://en.unesco.org/themes/education (consulted on date; 09.12.2018)
} 
Currently, UNESCO at world level, in the field of cultural and natural heritage, has 22 active programs and this is a missed opportunity for Kosovo because it could benefit in building institutional and human capacity, standardizing laws and implementing conventions. Youth would have access to education in different countries and exchange of experiences in the field of cultural and natural heritage, funds and projects would promote a new level of responsibility for the protection, conservation and management of all categories of cultural heritage. Membership in UNESCO also has obligations and responsibilities, such as advancing legislation, inventorying or creating a list of permanent assets, cultural heritage protection as well as preservation and management. Kosovo benefits because it enters the map of destinations of cultural heritage and cultural tourism. But there are also the financial benefits for programs that are implemented around the world, various funds for the advancement and standardization of education, science and culture in the form of grants. It should be noted that UNESCO in Kosovo has supported the restoration of the Novo Brdo Fortress worth several million even though we are not members of this organization. UNESCO Worldwide there is 2079 clubs, which are active. Kosovo would only benefit from twinning with clubs from countries that have recognized Kosovo's independence, expanded influence, but would also exchange experiences with clubs of countries that have not yet recognized its independence.

\section{CONCLUSION}

Kosovo's membership in various regional and international organizations does not imply direct or automatic recognition of its international subjectivity as a new entity. However, in practical terms, this form of action may aim to achieve that recognition as a political act. Kosovo has so far been able to sit on the same table with most of its neighbors and discuss on equal terms the various regional challenges.

Kosovo has proved that the Constitutional Framework, Laws, regulations and strategies are in harmony with all UNESCO Conventions and in particular for Education, Science and especially for the human rights and Cultural Heritage which requires not only laws and their implementation, but also institutional mechanisms for their implementation, this should be seen as an additional argument for defense mechanisms, which will be an additional argument for pledging respect for international conventions.

Finally, reforms in cultural heritage management, quality education, media freedom, gender equality, science and technology development and other areas of interest for UNESCO's work are of vital importance for Kosovo itself. Kosovo's membership in UNESCO will not only undermine the important legacy of Kosovo Serbs, but rather will create additional conditions and guarantees their protection in Kosovo. 
Kosovo must prove to the world that it is interested and ready to be positioned along the progressive countries and taking concrete legal and institutional actions for the preservation of cultural heritage values, with unilateral approval of UNESCO conventions, the proclamation of cultural heritage properties in permanent protection, drafting of management plans for cultural heritage properties, internal dialogue in Kosovo for Orthodox heritage monuments, treatment of illegal constructions within protected areas of heritage and adoption of new law and strategy national heritage.

\section{BIBLIOGRAPHY}

Midterm strategy of UNESCOS 2014-2017 Medium-term Strategy (37 C/4), the Programme and Budget document (37 C/5),

Admission of a State to the United Nations (Charter, Art.4), Advisory Opinion: I.C.J. Reports 1948 ,

Kosovo constitution http://kryeministri-ks.net/wpcontent/uploads/2018/03/Kushtetuta.e.Republikes.se_.Kosoves-2.pdf

UNESCO Constitution: http://unesdoc.unesco.org/images/0021/002161/216192e.pdf

Rules of Procedure found in UNESCO basic documents:

http://unesdoc.unesco.org/images/0021002161/216192e.pdf

Agenda of $38^{\text {th }}$ session of general assembly of UNESCO https://unesdoc.unesco.org/ark:/48223/pf0000233081 